\title{
9. Indigenous leaders and leadership: agents of networked governance
}

\section{Bill Ivory}

\section{Introduction}

In 2007, the Prime Minister of Australia, The Hon. John Howard, ${ }^{1}$ introduced a policy of unilateral intervention into Indigenous communities in the Northern Territory (NT), purportedly to address the overwhelming incidence of child abuse. In doing so, he argued that 'The basic elements of a civilised society don't exist'. $^{2}$ His main Ministerial proponent of the intervention, The Hon. Mal Brough, the Minister for Families, Community Services and Indigenous Affairs, justified the nature of the initiative by characterising Indigenous people in the NT as having a dysfunctional society where 'strong men prevail' (Howard and Brough 2007). In addition, the Federal Health Minister, Mr Tony Abbott, referred to 'big men' who are 'terrorising' other Aboriginal people (ABC 2007).

These views are reminiscent of those of commentators such as Helen Hughes (2005: 16), who recently argued that 'Small elites of "big men" monopolise the layers of separate governance created for Aborigines and Torres Strait Islanders'. According to Hughes (ibid.), 'Sorcery and payback thrive. The ultimate results are murders and suicides'.

In a similar vein, another commentator (Hirst 2007) wrote in one national newspaper that 'in many Aboriginal communities ... [t] he people have shown they are incapable of governing themselves. There is no point in consulting them about the creation of authority; authority has to be created for them'.

When issues arise about the functionality of Indigenous communities, politicians and public commentators regularly question whether there is, in fact, any extant Indigenous governance and leadership. Some argue that if it once existed, it has since become valueless or has disintegrated altogether. Many regard Indigenous leadership as being so politically under-developed and socially ephemeral that it is ineffective in mobilising law and order.

It is perhaps not surprising then, that when The Hon. John Howard's VIP aircraft landed at Wadeye (Port Keats) in the NT in early April 2005, Australia's national leader, accompanied by senior bureaucrats, appeared keen to make his visit as brief as possible. Receiving a salute from an Aboriginal soldier in army uniform,

\footnotetext{
${ }^{1}$ Prime Minister Howard's Federal Coalition party lost government during the Australian election held on 24 November 2007.

2 Interview with David Koch and Melissa Doyle, Sunrise, Seven Network, 22 June 2007, transcript available at <http://pandora.nla.gov.au/pan> [accessed 24 April 2008].
} 
he shook hands with a local Aboriginal landowner and council representative and then hurriedly moved on. Under a nearby tree, unnoticed by the official party, were several bemused elderly Aboriginal gentlemen, one in a wheel chair, patiently watching the events unfold, and waiting to welcome their official guest. These men were in fact senior leaders ${ }^{3}$ of the Port Keats region, experts in group survival, directors of ceremony, and adept at negotiated decision-making and consensus building. ${ }^{4}$ Most had spent time 'droving bullocky' as expert stockmen, working for the cattle barons of the NT, and more recently had been engaged in establishing representative organisations within the community. Later, they were briefly acknowledged by the Prime Minister as his party swept on through the community. Meanwhile, Aboriginal community residents, well aware of the importance of these old men, respectfully gave them their due deference and attention. ${ }^{5}$

In the wider historical context of Indigenous affairs and the NT intervention, this scene raises important questions. Why is it that in Australia, Indigenous leaders are often disregarded or at best grudgingly recognised by non-Indigenous people and their leaders? Why is Indigenous leadership seemingly invisible to non-Indigenous eyes? Is Indigenous leadership so politically under-developed that it is ineffective in today's post-colonial Australian society? Are the leaders themselves content to sit in the background and let the intercultural vortex marginalise them?

This chapter draws on field research conducted at Port Keats to examine the conditions for the reproduction and enactment of Indigenous leadership with the aim of bringing both the concept and practical workings of leadership into sharper relief in the contemporary Australian intercultural setting. A model of networked Indigenous leadership is proposed that enables us to better understand how Indigenous leaders are produced and developed, and how local Indigenous societies, at least to this point, have been able to promote cultural resilience and collective survival. To do so, the chapter looks back at the leadership history of the community and the personal life histories of people who are regarded by their peers and kin as 'leaders'. It also positions Indigenous leadership and governance within the wider environment of mainstream Australian governance

\footnotetext{
3 These men were senior leaders (among others) within their clan-groups and also within the wider ceremonial arena. Each clan, and there are 20 within the Thamarrurr region, has senior leadership. As the Prime Minister was entering a particular clan's land, referred to as the Kardu Diminin, these men were the appropriate authority figures for this occasion.

4 Two of these senior leaders have since passed away.

5 The Prime Minister was at Wadeye to acknowledge its prominence as the selected NT trial site for a major Council of Australian Governments (COAG) initiative. In April 2002, COAG had introduced the initiative in order to develop integrated and flexible programs and services for Indigenous people in eight sites across Australia, one in each State and Territory. Each trial was led by one Australian Government and one State Government agency.
} 
and explores possible options for creative engagement between the two domains, and for the sustainability of Indigenous forms of leadership.

\section{Colonial views of Australian Indigenous leadership}

There are many publications that provide important insights into Australian Indigenous leadership, particularly in its regionally differentiated, gendered and religico-ritual contexts. ${ }^{6}$ Often the terms 'leader' or 'leadership' are not to be found in the text of these publications, as writers have referred to headmen, chiefs, bosses, elders and so on. Whilst the literature on contemporary Indigenous leadership illustrates a wide spectrum of views, in early colonial Australia descriptions were perhaps even more varied, although possibly more tightly bound by the conceptual constraints of the social evolutionist thinking that prevailed in early colonial accounts of Indigenous Australian life.

Debate has ensued since Captain Cook's first landing about whether Australian Aboriginal people even had systematic forms of 'leadership' and governance, and if they did, what they looked like. Early colonial assumptions and opinions were formed under the ideological umbrella of the European Enlightenment, which Burch and Ellanna (1994: 1) have described as 'political philosophy, not science' with its 'arguments and assumptions ... based more on fantasy than fact'. One early commentator, in 1793, was concerned that there did not appear to be 'any civil regulations, or ordinances ... [existing] among this people' (Tench 1961: 51).

Sixty years later, reflecting a common opinion of the time, a journalist and historian writing in 1853-54 argued that Aboriginal people had 'authority or unity of no description' and that they had 'no chiefs' (Flanagan 1888: 15).

These early constructs of Indigenous leadership were often based on European military and institutional paradigms as well as past colonial encounters with natives elsewhere. There was a yearning amongst British settlers and observers for visible structures of government, clear hierarchies of power and authority, plus written laws. The assumptions and biases of social evolutionist perspectives that emerged from the colonial era were further developed within public policy and anthropological thought in the nineteenth and early twentieth century. A summary of these chronological views is given in Table $9.1 .^{7}$

\footnotetext{
6 Table 9.1 outlines some of the writings about Indigenous leadership. Other researchers (Anderson 1988; Bern 1979; Edwards 1987; Hiatt 1986, 1996; Keen 2006; Smith 1976) have previously reviewed the literature on Indigenous politics and leadership.

${ }^{7}$ Table 9.1 reflects various perspectives on Indigenous leadership but it is not intended to be definitive. Some analysts employ a range of leadership descriptions, such as 'old men', 'mature men', 'men of power, authority and influence' (see e.g. Stanner 1979), and so on. For my purposes here, however, a particular analyst might be mentioned in only one category.
} 
Table 9.1 Paradigms of Indigenous leadership

\begin{tabular}{|c|c|c|}
\hline TYPE & PROPONENT \& PERIOD & BRIEF DESCRIPTION \\
\hline Chief or chiefs & $\begin{array}{l}\text { Tench (1961) [1793], Batman [1835] } \\
\text { in Billot (1979), Grey (1841), Taplin } \\
\text { (1874), Dawson (1881), Thomas, W. } \\
\text { [1898] in Bride (1969) }\end{array}$ & $\begin{array}{l}\text { Chiefs but no 'civil regulations'; chief } \\
\text { selected by family heads; authority over } \\
\text { a certain territory; government is } \\
\text { patriarchal. }\end{array}$ \\
\hline Head of group & $\begin{array}{l}\text { Collins (1804), Thomas (1906), Wheeler } \\
\text { (1910), Elkin (1938), Biskup (1973), } \\
\text { Von Sturmer (1978) }\end{array}$ & $\begin{array}{l}\text { Family heads; assembly of elders; 'past } \\
\text { masters'; local group headmen; } \\
\text { ceremonial headmen/ political power. }\end{array}$ \\
\hline No Chiefs & \begin{tabular}{|l|} 
Wilkes (1845), Eyre (1845), Flanagan \\
(1888) [1853], Radcliffe-Brown (1913)
\end{tabular} & $\begin{array}{l}\text { 'Laws'; no authority/ no chiefs; no tribal } \\
\text { chief, nor any form of tribal government. }\end{array}$ \\
\hline Old men & \begin{tabular}{|l|} 
Smyth (1878), Spencer and Gillen \\
(1938) [1899], Strehlow (1947), \\
Stanner (1979) [1953], Sackett (1978), \\
Rowse (1998)
\end{tabular} & $\begin{array}{l}\text { Men who 'took the lead'; headmen of } \\
\text { council; leaders; ceremonial chiefs; } \\
\text { mature men. }\end{array}$ \\
\hline $\begin{array}{l}\text { Eminent, prominent, } \\
\text { influential, and great men }\end{array}$ & $\begin{array}{l}\text { Howitt (1967) [1880], Curr (1886), } \\
\text { Elkin (1938), Maddock (1972), Kolig } \\
\text { (1981), Keen (1994) }\end{array}$ & $\begin{array}{l}\text { 'Men of note'; prominent men; bosses } \\
\text { or 'bunggawa'l 'looking after' others; } \\
\text { networks; local and personal authority. }\end{array}$ \\
\hline Men of authority & Bern (1979), Keen (1982) & Prestige and authority through religion. \\
\hline No headmen & Sharp (1958), Meggitt (1962) & $\begin{array}{l}\text { No leaders, headmen, or chiefs; } \\
\text { kinship-related social rules. }\end{array}$ \\
\hline Senior men & Hiatt (1965) & Clan-based senior men \\
\hline Big men & $\begin{array}{l}\text { Berndt and Berndt (1965), Von Sturmer } \\
\text { (1978), Sutton (1978), Chase (1984) }\end{array}$ & $\begin{array}{l}\text { 'Bosses'; kinship system of leadership/ } \\
\text { hierarchical ordering. }\end{array}$ \\
\hline Elders & Gould (1969), Collman (1988) & $\begin{array}{l}\text { Elders but no official leader; tribal elders } \\
\text { interacting with bureaucracy. }\end{array}$ \\
\hline Leaders & \begin{tabular}{|l|} 
Rigsby (1997) [1982], Sutton and \\
Rigsby (1982), Tonkinson (1991) \\
[1978], Williams (1987), Smith (1997)
\end{tabular} & $\begin{array}{l}\text { Ritual leaders; 'politicks', political } \\
\text { structures and leadership; } \\
\text { context-based; hierarchical clan-based } \\
\text { leadership/ networks. }\end{array}$ \\
\hline Managers & Burridge (1973) & Middle-aged men who 'managed'. \\
\hline Authority \& Higher order & Myers (1976) & $\begin{array}{l}\text { Authority through progressive growth/ } \\
\text { 'looking after' others. }\end{array}$ \\
\hline Masterful men & Sansom (1980) & Men with business acumen. \\
\hline $\begin{array}{l}\text { Dominant } \& \text { adventurous } \\
\text { men }\end{array}$ & Gerritsen (1981) & $\begin{array}{l}\text { Control of public sector/ appropriation } \\
\& \text { sharing of benefits amongst followers. }\end{array}$ \\
\hline 'Experts' & Trigger (1992) & $\begin{array}{l}\text { Context-based on two domains; joint } \\
\text { status; middle-men. }\end{array}$ \\
\hline
\end{tabular}

NB: When the date of observation/description differs from that of publication it is noted in square brackets.

This summary suggests that major shifts in perspectives on Indigenous leadership have occurred at key periods of Australian history. Nineteenth century reports on Indigenous leadership favoured a social evolutionist approach, whilst during the early twentieth century, research began to be informed by the functionalist and structuralist approaches of British anthropology. More recent field-based research has drawn more widely from political science, political economy, and French structuralism, in order to yield more detailed knowledge of the complexity of Indigenous leadership in its local variations.

This more recent literature (see Table 9.1) can be summarised as proposing that Indigenous leadership in Australia has the following characteristics:

- it is founded on group-based structures, tending in some cases to be hierarchical (kinship, marriage and social bonds define and bind such groups, often to the point of being characterised as an inflexible blue-print for action); 
- it is constructed and practised among groups with regional variations;

- it is highly contextualised and gender-specific;

- men (and women) commence their leadership 'training' from an early age and such socialisation continues through life;

- age and knowledge play an important part in defining one's position in the leadership hierarchy;

- some men and groups become more influential than others through their own personal attributes, or by the accumulation of power through ceremonial means, women, followers, and access to other desired resources; and

- such influential men can broaden their leadership base and prowess by further developing social ties through reciprocal obligations, which can develop into complex networks of authority and power, and may be influenced by contemporary arrangements and resources. The literature occasionally refers to such individuals as 'big men' and notes that such 'bigmanship' ${ }^{8}$ may only be temporary.

Unlike the issues of Indigenous land ownership, territoriality, kinship models and religious life, there does not seem to have been a progression from these useful insights, towards a more cohesive theoretical analysis that illuminates the historical and contemporary conditions, workings and transformations of Indigenous leadership in the inter-cultural context.

Much of the research evidence so far has been developed by anthropologists and others observing specific groups in various areas of Australia. A key related challenge is whether such evidence can be generally applied across the whole of Australia, and whether regionalism and other cultural factors make for influential similarities and differences in the conditions and enactment of leadership.

\section{Leadership in the Port Keats region}

Research I conducted in the remote Aboriginal-owned area referred to as Port Keats $^{9}$ or Wadeye has enabled me to identify key conditions and features of Indigenous leadership over several generations. These inform a model that conceptualises how leadership operates to establish governing order and how it is reproduced and transformed, and which illuminates how that leadership has responded to external changes and contact over generations.

The reality of life and research in Indigenous Australia is that there is a gendered framework for how secret knowledge is maintained and passed on. There are distinct male and female rites of passage through which leaders pass, and gendered contexts where leadership may be performed. As a man, this has meant

\footnotetext{
8 The term 'bigmanship' is used by Hiatt (1986: 14).

${ }^{9}$ Port Keats is the region and Wadeye is the town. Aboriginal people often refer to their 'home' as Port Keats.
} 
that my research has inevitably focused on male leadership. An important caveat, then, in my attempt to develop a more cohesive, analytically useful model of Indigenous leadership, is that my research has been primarily about and with male leaders. It could legitimately be said that what I am describing is only half of a symbiotic system of overall leadership in community life. I would argue, however, that this does not detract from the salience and validity of the model and analysis presented here, as my research has also been informed over many years by numerous discussions and interactions with female leaders and senior women in families amongst all the clan groups in the community and surrounding region. I have travelled extensively with senior women, undertaken 'return to country' and site mapping with them, and worked with a number of women in their official capacities as representatives in community organisations. ${ }^{10}$ To that extent then, my analysis has also been considerably influenced and moulded by women's views and information, as well as by those of male leaders in Wadeye.

My perhaps audacious hypothesis is that despite clear gender differences in the context and style of male and female leadership, research with women by a woman would generally confirm that the same broad structural, institutional, sociological and political conditions for the production and reproduction of leadership apply to both men and women's leadership. Accordingly, where relevant and to the extent of my knowledge, I have presented comparative information on female leadership at Wadeye; but the clear and primary focus of my analysis here is on male leadership.

\section{The structural and systemic bases for contemporary Indigenous leadership}

The Port Keats region is situated $320 \mathrm{~km}$ southwest of Darwin in the NT. It is relatively isolated and is inaccessible by road during the wet season. The population of predominantly Aboriginal people was estimated to be 800 in the early 1970s, rising to its current total of approximately 2300 Indigenous languages and dialects in the region include Murrinh-patha, Marri Ngarr, Magati-ge, Marritjevin, Marri Amu, Emmi, Menhthe, Ngan.gi-tjemerri, Ngan.gi-wumeri, and Ngan.gi-kurunggurr. ${ }^{11}$ Murrinh-patha is generally understood as the 'universal' language amongst the Aboriginal community residents. Some residents, particularly the elderly, also speak languages to the southwest including Djamindjung, Ngaliwuru and Miriwung.

\footnotetext{
${ }^{10}$ Female leadership is prominent in the Port Keats region but was not the primary focus of this particular research. Nevertheless, Indigenous female leaders provided valuable information, advice and assistance.

11 This list of languages and dialects (and the spelling) corresponds to that of Dixon (2002).
} 


\section{Fig. 9.1 Port Keats/Wadeye regional map showing localities and pastoral stations (shaded areas) mentioned in the text}

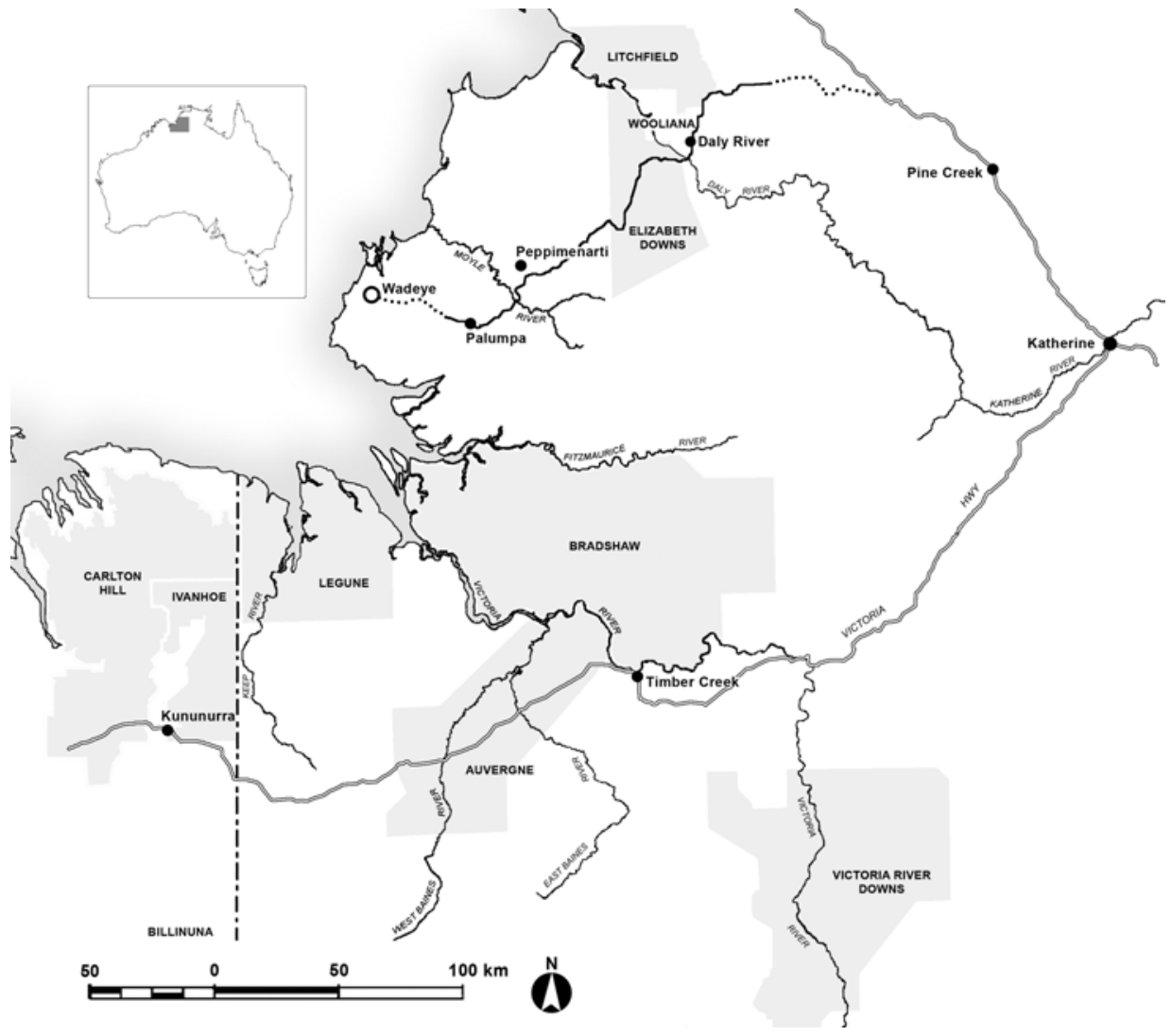

People from the region have a long history of contact with other Aboriginal groups particularly north toward the Daly River and south toward Timber Creek. These contacts have ebbed and flowed depending on events, but they were probably at their height when labour from Port Keats was accessed for pastoral work.

A tripartite ceremonial structure, made up of the Dhanba/Wurlthirrii/Malkarrin, Wangga, and the Lirrga ceremonial groups (and representing the various language groups), exists in the Port Keats region today. ${ }^{12}$ This structure is foundational in determining relationships and interaction between individuals and groups.

\footnotetext{
12 The spelling of these ceremonial and song genres varies. The spelling used in this case is that used by Marett (2005), an ethnomusicologist who has done considerable work in the region.
} 
There are numerous patrilineal clan groups with specifically-owned estates in the region. ${ }^{13}$ Each clan has a hierarchical structure of authority for the conduct of certain affairs that is recognised by its membership. The primary decision-makers for each clan are the men referred to as kardu pule or 'bosses'. By various means, some individuals also gain higher levels of authority across clan boundaries. Whilst such authority exists, it is also important to acknowledge the underlying egalitarian nature of the society and individualistic rights, for these form the foundation within which leaders function.

\section{Fig. 9.2 Murrinh-patha age categories}

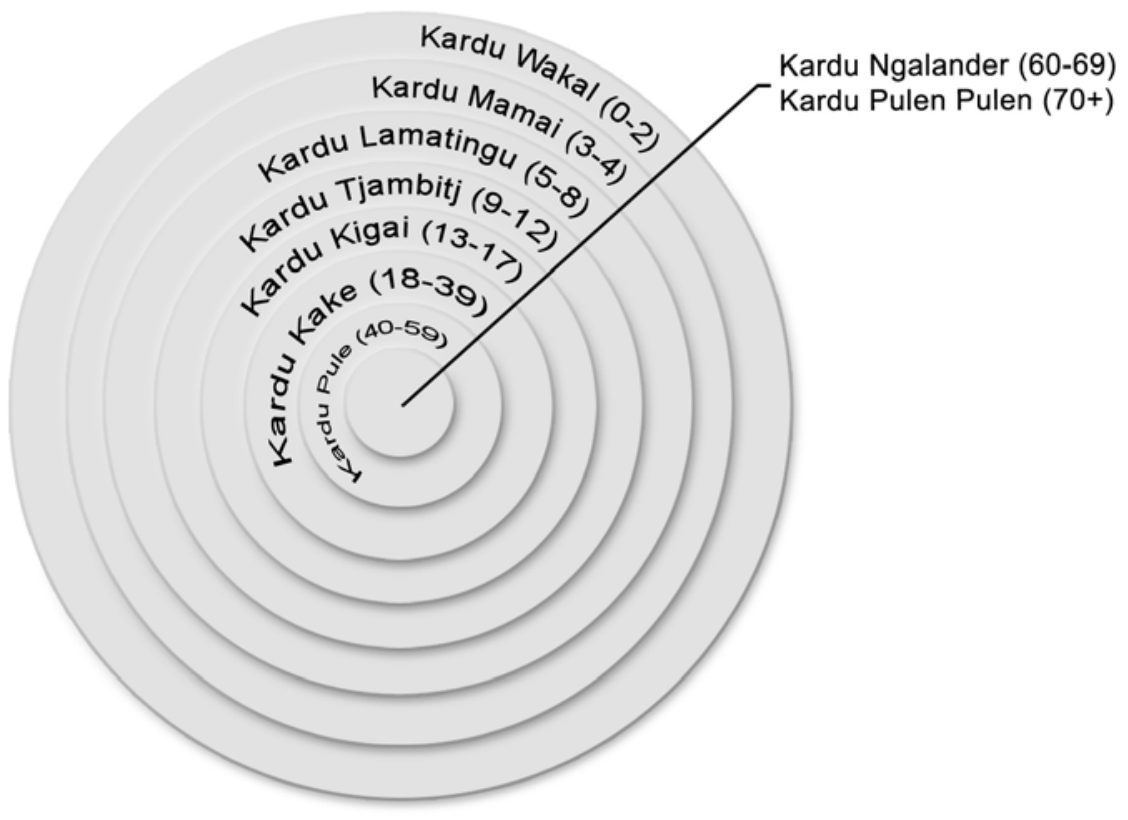

\section{Murrinh-patha Age Categories}

As they age, young boys progress from the outer circle toward the centre. Older men in the centre have superior knowledge and experience.

From a fairly early age, young men at Port Keats begin to proceed through certain rites of passage (see Ivory 2005b: 4-5). Such passage is marked by categorisation

\footnotetext{
13 The use of the term 'clan', and its appropriateness, is debated in the anthropological discourse. Nevertheless, the Port Keats people regularly use the term to describe the basic land-owning group in their region and I have followed suit.
} 
into particular age groups (see Fig. 9.2). Indoctrination and learning is conducted in formal and informal circumstances. Male and female leaders from the clan teach the young about their clan estate, its associated mythology, and how to survive using that knowledge. Formal learning is usually associated with three ceremonies where initiates learn about sacred aspects of Aboriginal religion, norms of the society, and build a special relationship with their peers and the senior leaders.

Today, social development is continuing in the Indigenous domain at Port Keats. The question then, is whether Indigenous leaders are able to participate in the non-Indigenous domain as well, and if so, how? And how has the leadership situation evolved over time to enable forms of inter-cultural leadership engagement?

\section{Leadership in the intercultural domain}

Leaders in Port Keats have, over the years, developed different structures for collective leadership in the intercultural domain.

A local council, Kardu Numida Inc, was established at the township of Wadeye in 1979 (Thamarrurr Regional Council 1995: 4). The council was to act as a stable form of local government authority and supply local government-type services. It was established under the Associations Incorporations Act 1963 (NT), legislation that was originally intended for 'football clubs and bingo groups' (D. Read, Assistant Director of Northern Territory Department of Community Development, pers. comm., 1978). However, although the NT and Australian Governments recognised this entity, it was 'often not seen to be the valid decision making structure in the eyes of local Aboriginal people' (Desmarchelier 2000: 2).

The electoral process of the Kardu Numida Council required annual elections, with 15 people to be nominated from family groups belonging to each of the three larger ceremonial groups referred to above. Over time it became apparent that leaders from outside of the Kardu Diminin clan (Dhanba group) were feeling increasingly uncomfortable about making decisions related primarily to land on which the community was located, but which was traditionally owned by another clan. As a consequence, by 1994 the leaders outside of the Kardu Diminin had virtually withdrawn their participation from the Kardu Numida structure. Financial problems associated with inappropriate funding levels for a community that had doubled in population signalled the end for the council in this form.

\section{The development of Thamarrurr}

Commencing in 1996, at the end of the Kardu Numida era, a deliberate move was made by the Kardu Diminin clan leaders, in conjunction with other clan leaders, to correct what was seen as a past governance imbalance. The governance structure they now developed was a culturally-based concept of conflict 
resolution and power balance, referred to in the Murrinh-patha language as Thamarrurr. This model effectively recognises the relationships between individuals, groups and clans.

Formal recognition of the clan as a primary node of authority and the notion of the Thamarrurr model, in some of its dimensions, was transposed into a NT local government scheme under the Local Government Act for the region in 2003. The people of the Port Keats region perceived this as a major repositioning of the traditional authority structure with contemporary Australian governance. The leaders envisaged that with this model they would be able to engage more effectively with wider Australia and move forward. It was seen as the foundation for dealing with social, political and economic issues that had emerged for them as the dominant wider Australian culture further influenced and changed the Indigenous cultures of the region.

\section{The concept of Thamarrurr}

Prior to colonisation, the people of the Port Keats region lived on country that was rich in food and resources, and also rich in religious meaning. The land supported a relatively high density of population of approximately 3,000 people, compared to other parts of Australia (Ivory 2007). During visits commencing in 1934, the anthropologist William Stanner observed that the society was structured into segments, with the primary division being the clan. Each clan had a fairly strictly defined territory delineated by physical markers and sites associated with mythological beings that were known by both men and women (Stanner 1964: 32).

Clan estates were relatively small and close together. Each estate was zealously watched over by members of the clan and there was regular warfare related to disputes that differentiated and defined relationships and ownership of territories and resources. Social life, according to Stanner (1964: 31) was a volitional and purposive system deferring to tradition. Relationships between individuals and groups were governed by a system referred to as Thamarrurr. In the Murrinh-patha language, Thamarrurr Region Councillors articulated this concept as follows:

It is our way of working together, cooperating with each other, and it is also the basis of our governance system.

In the early days we looked after our families, our clans and our people through Thamarrurr. We arranged ceremonies, marriages, sorted out tribal disputes and many other things (in Taylor 2004).

According to Stanner (1964: 37), certain aspects of the local culture were 'working toward' a 'unified system or unified whole' in the 1950s, which eventuated in the 1960s. An example of this transition is the ceremonial structure, which over 
time became more and more isolated from countrymen in places such as Kununurra, Timber Creek, and the various cattle stations where they had worked. This had occurred primarily because of the breakdown of job opportunities outside Port Keats and a subsequent lessening of social interactions with these other Aboriginal groups. ${ }^{14}$

Today, the clan unit is still the key structure of importance. Clan members and outsiders are very knowledgeable about their clan estates and fulfil their responsibilities to such country to varying but significant degrees. On occasions in the past, a group might have been pushed off country by the might of the spear or a more amicable arrangement reached, but this is unlikely today as land rights enshrined in Australian law have brought a new definition and permanence to land ownership. ${ }^{15}$

The rights of the individual within a socially situated group context are still paramount today, as is the right to take matters to another level if one is considered to be aggrieved. Where there were once 'hordes', 'gangs' and 'fire-places' of anthropologically classified groups (Falkenberg and Falkenberg 1981: 69-75), now there are council houses in suburban enclaves, but still within demarcated cultural spaces. Alliances are constantly worked on and nurtured, particularly through marriage and kinship, and cultural trade referred to as nandji kulu continues and respective affiliations are cultivated.

Despite the influence of outside contact, many of the structures and aspects of culture today remain similar to when the missionaries first arrived in 1935. Ceremonies and rituals are maintained within the constraints of contemporary conditions and people hold strong family and clan affiliations and relationships. The reconfiguration of song genres in the 1950s onwards, as described by Furlan (2005), demonstrates a desire to reproduce Indigenous values within a paradigm of modernity. Individuals are socialised within a cultural context but amidst the environment of a burgeoning town. Leaders are identified and trained, and then eased on to a 'stage' that increasingly operates in the intercultural with various political, social and economic responsibilities.

The concept of Thamarrurr means all of the above and more. Local clan leader Tobias Nganbe ${ }^{16}$ (pers. comm., 2005) describes it as 'a way of life' and a means of cooperation and governance. Further he advises that it is foundational to the mental construct and world-view of local people.

\footnotetext{
${ }^{14}$ Relationships are still maintained with such northern and southern groups but not to the same degree. People in the past would walk back and forth from Port Keats to Bradshaw Station, for example, but this has not happened for many years. Nevertheless, there are still air and road visitations when funds are available.

15 The Aboriginal Land Rights (Northern Territory) Act 1976 (Cth) enabled some Aboriginal people in the NT to gain inalienable freehold title to their traditional land.

16 Tobias Ngambe is co-principal of Our Lady of the Sacred Heart Catholic School, Wadeye, NT.
} 


\section{Adaptations of leadership: challenges from without}

There has been a series of landmark events that have challenged the leadership model of Port Keats. My research (Ivory 2005b, 2006, 2007) indicates that these events include the:

- early intrusions by explorers, miners and others;

- advent of pastoralism and occupation to the south of Port Keats from 1870;

- introduction of associated diseases that decimated the Aboriginal population;

- arrival of missionaries in 1935;

- World Wars One and Two;

- opportunity to participate and work in mainstream economic society;

- advent of welfare payments, including unemployment payments or 'sit-down money', when suitable work ceased;

- establishment of a community council in 1979;

- establishment of the Aboriginal and Torres Strait Islander Commission (ATSIC) and a regional ATSIC council for the wider area in 1990; ${ }^{17}$

- establishment of a NT local government council in the Port Keats region in 2003 and then further local government reform from 2006; and

- pressure to participate in an Australia-wide Council of Australian Governments' (COAG) trial from 2003. ${ }^{18}$

Finally, the challenge that emerged in 2007, that continues today, is one of 'intervention' by the Australian Government, where many Indigenous leaders are being told that they are ineffective, irresponsible, and unable to deal with issues such as child abuse.

History reveals that Indigenous people in the Port Keats region have had to deal with significant social change in the past. My historical and ethnographic field research indicates that each time a challenge is thrown up for Indigenous leaders of the region they respond - repeatedly seeking positive engagement and making adaptations in the process. Below I present three examples from the above list to highlight the nature and impacts of this 'responsive engagement' by leaders.

\footnotetext{
17 ATSIC was a key element of the Commonwealth Indigenous affairs administration and representation for 14 years. Representation was divided into regions and the Port Keats area was part of a wider representative region that included many other communities. There was effectively one representative from Port Keats. The Coalition Government abolished ATSIC in 2004.

18 COAG is the peak intergovernmental forum in Australia, comprising the Prime Minister, State Premiers, Territory Chief Ministers and the President of the Australian Local Government Association (ALGA). In 2002, COAG, in a reaffirmation of its commitment to advance reconciliation and address social and economic disadvantage of Indigenous Australians, agreed to a trial of a whole-of-government cooperative approach in up to 10 communities and regions. The NT Government put forward Wadeye as its trial site.
} 


\section{Example 1: Pastoralism and occupation}

Early European occupation on country south of Port Keats occurred from the 1870s. Settlers established Victoria River Downs, Bradshaw, Legune, Auvergne and other pastoral properties (see Fig. 9.1). There was an immediate response from Aborigines in the region, including Port Keats, to initiate relationships with the newcomers. Aboriginal men and women, with their families, moved to these cattle and sheep stations, often taking work for rations as stockmen, station hands, domestics and the like. Others camped on the outskirts of the properties, later moving closer to the respective station as relationships flourished.

Aboriginal people were keen to proffer their services in exchange for European goods such as tobacco, tea, sugar and flour. Whilst 'the network of relations' between Aboriginal groups in the wider region was disturbed (Stanner 1964: 109), it was also rapidly adjusted as leaders negotiated their positions. The decision to engage and adapt was made by the clan leaders. In doing so, they retained their own status as leaders whilst exposing their clan group to the influences of non-Aboriginal society, both positive and negative. The leaders and their followers also commenced engagement in a new phase of non-Indigenous economic life. Through Indigenous religious experience and ceremonial exchange, new political relationships between leaders from Port Keats and those further south were re-defined and reinforced.

\section{Example 2: The arrival of the mission}

The Commonwealth Government encouraged church endeavour during the early 1900s in the Top End, mainly due to their own inability at the time to deliver services. On hearing of the arrival of Father Docherty and fellow missionaries in 1935, the clan leaders, almost unanimously it seems, welcomed their arrival. The missionaries brought goods, a new economic and political system, as well as an alternate religion.

Aboriginal leaders led them to water supplies and suitable land for settlement and later agreed for the main community to be built at Wadeye on suitable high ground. They brought their children into the Church and entrusted them to the missionaries for education within the dormitory system. They supported and worked with the missionaries in market gardens, forestry, pastoral and other ventures.

The impact of this phase of engagement on the leaders and patterns of leadership was substantial. Some leaders were regarded as being 'in' with the missionaries and gained access to new resources and opportunities. The power base of those leaders who worked with the missionaries was enhanced, while others who were not so in favour moved further afield to cater for the needs of their group. Nevertheless, the dynamic nature of the leadership construct continued. Even though some leaders were engaging with the missionaries and others were not, 
the clan-based leadership construct remained strong, as did reliance on both the existing and newly established Indigenous networks of relationships. ${ }^{19}$

\section{Example 3: Local government reform and Commonwealth intervention}

In more recent times, and despite such efforts by the leadership to engage, both the NT and Commonwealth Governments began to move toward revised policies of intervention in 2006 and 2007.

From mid 2006, the Commonwealth Government began to intervene in community affairs at Wadeye. They were keen, through the Indigenous Affairs Minister, The Hon. Mal Brough, to effect practical changes in terms of law and order, housing, and individual behaviour. Following a NT Government report on child abuse, publicly released in June 2007 (Anderson and Wild 2007), the Commonwealth announced fundamental changes to its mode of policy intervention. This announcement primarily targeted law and order, education, and health.

Contemporaneously, in October 2006, frustrated at the level of perceived 'dysfunction' (Ah Kit 2002: 2) in Indigenous communities, the NT Government announced through their Minister for Local Government, The Hon. Elliot McAdam, a new policy of mandatory regionalised, amalgamated local government (see McAdam 2006). This, he argued, would provide better basic services and be economically sustainable.

The NT Government's initiative of local government reform meant that the Thamarrurr Regional Council, constructed by the Port Keats leadership only four years earlier, would no longer be the formal local government authority in the region. The Thamarrurr region will form a ward of a larger shire council on 1 July 2008 and have four representatives on the new council. ${ }^{20}$ The leaders, having to readjust their quest for positive engagement once again, have reportedly now focused their attention on restructuring the Thamarrurr model to be the economic development body for the region, whilst also tacitly accepting the new local government regime.

Despite an ever-changing environment, these three examples suggest there has always been a substantial degree of willingness on the part of leaders and groups at Port Keats to actively engage with external agencies and survive. Indigenous accommodation and reconstitution has repeatedly occurred in response to massive interventions that, in some instances, included challenges on physical and

\footnotetext{
19 Often those leaders who did not actively engage had an ongoing dispute with another family member (who had formed a relationship with the missionaries) and this impeded their own engagement.

20 The draft business plan for the Victoria Daly Shire Council (December 2007) proposes that there be four representatives for Port Keats on a council of 12. See: <http://www.localgovernment.nt.gov.au/ _data/assets/pdf_file/0009/32013/Victoria_Daly_Shire_Business_Plan_-_Main_Report_1st_Draft.pdf $>$ [accessed 1 May 2008].
} 
psychological fronts. It was only the resilience of the people and leadership adaptations that enabled them to re-engage with a succession of outsiders and continue their lives (see Ivory 2005a: 1-15). The evidence strongly challenges the supposition that Indigenous leadership was, and is, ill defined and unresponsive. However, challenges to Indigenous leadership at Port Keats have not all come from outside their local political domain, they have also come from within their own society.

\section{Adaptations of leadership: challenges from within}

During the late 1980s, groups of young men and women from Port Keats began to create their own social constructs and 'way of being' in the form of groups (sometimes referred to by the media and others as gangs). They increasingly manoeuvred themselves into a powerful bloc on the socio-political scene at Wadeye. The groups refer to themselves with often brazen names such as Evil Warriors, Judas Priest, Fear Factory, Big T and so on (see Ivory 2003). Many of the names are derived from western heavy metal band culture (ibid.: 65-6).

In general, the 'youth' in these groups have poor education, are unemployed, and aged between about $8-30$ years. They might be described as the angry young men of Port Keats and have emerged post-mission. ${ }^{21}$ Fifty years ago, Stanner (1964: 109) had written about the 'noticeable' change in young adult males as 'traditional circumcisions' ceased. The older men spoke about the 'indiscipline of the new generation' and their 'disrespect toward authority' (ibid.).

It is evident that the contemporary youth groups of Port Keats have characteristics of their own when compared to mainstream constructs of gangs throughout the world. In addition to 'normal' youth gang attributes, they have strong affiliations to Indigenous kin, country, and family, and a strong desire to be recognised positively from within their own Indigenous society. They have constructed their own subculture and developed a collective response - albeit a deviant one on some occasions - in order to resolve contradictions that are present in relation to their own culture (Ivory 2003). Whilst the middle-aged, in conjunction with the elders, have constructed and defined a positive role for their cohort, this third group has constructed its own networks and nodes of leadership based on a seemingly more negative worldview. Interestingly, however, many of these networks and constructs mirror the segmentation observed by Stanner 70 years ago and may not be quite as negative as they at first appear.

During the period of my research, particularly from 2002 until early 2006, relationships deteriorated between the youth of Port Keats and the older and middle-aged groups, as well as with the non-Indigenous sector. Conflict between

\footnotetext{
21 The groups consist of both males and females; however, young men are predominantly associated with conflicts.
} 
the youth groups was a common scene in Wadeye. It reached a point in March 2006, following a major outbreak of violence amongst the groups, when the leaders took affirmative and conciliatory action. The older and middle-aged clan leaders, aware of the affiliations, strength and positive connectedness of their societies' networked systems, but also aware of the divisiveness that could be generated, met as a group. Their previous strategy had been to attempt to ignore and not acknowledge the youth leadership and their dysfunctional behaviour. This time they decided to talk, recognise, and re-engage.

In conjunction with the youth groups, they developed plans enabling the youth to move back onto their respective land, be supported by the Council and the leaders, participate in positive work activities, and be recognised as a legitimate bloc. A key objective of the plan was to use kin relationships to reincorporate and re-centre the Indigenous youth back into family networks and life. This took the pressure off the community at the time, and although many of the younger groups later moved back to Wadeye, they now see living out on country as an option, particularly at times of stress. This solution, over simplified here, and precarious at times with a regular need for reconciliation, has enabled the wider community to move on. It is a further example of Indigenous leadership assessing the situation and readjusting their stance in order to retain the overall cultural fundamentals as well as their authority.

\section{The life history of individual leadership development}

An understanding of individual experiences of leadership development in the region is required to provide a greater level of understanding of how leadership operates. Individual case studies of three pre-eminent leaders, each from a different age group, are presented below. ${ }^{22}$ The first is about a man in his seventies, the second of a man in his forties, and the final case study is of a youth group leader in his late twenties.

\section{Case study A}

Mr J was born in the Wadeye Church Hospital in 1942. The Japanese had bombed the town of Darwin only a few months earlier. He was initiated in the bush when he was about ' 8 or 9'. Mr J recalls spending much of his early life on his father's clan estate. It was a time of much tribal conflict. War parties intent on capturing women would come down from Daly River and Pine Creek. He said they were 'Ngan.gi-tjemerri, Brinkin, Wagaman, Mulluk-Mulluk tribes and others'. He says:

Sometimes the bastards would surprise us and we would have to run and hide until they left. But then my father and his brothers would join

\footnotetext{
22 These case studies are based on interviews conducted with the individuals concerned. The names of the men have been abbreviated.
} 
up with men from other clans and go and steal their women. It was wild days then!

Mr J informed me that a place of refuge when any intruders came on to country was a small sand island near the mouth of the Fitzmaurice River. Adults and children would walk across to the island at low tide, and because the going was treacherous they were not followed.

At the time of Mr J's youth, Stanner was excavating an archaeological site on Mr J's country. Stanner had befriended Mr J's father and they all camped at the site together. At this time, Mr J's father was still making spear and axe-heads out of stone. The women would collect seeds and berries and grind them in the rock hollows at the shelter.

Soon after, Mr J was sent to the dormitory at Port Keats to be educated by the missionaries. He was allocated an identification number, as were all the others in the dormitories. He recalls how he detested this life, because the missionaries were often very strict with their punishments. At the age of about 13 he ran away in the company of his uncle. They walked from Port Keats to Daly River (a distance of about $180 \mathrm{~km}$ ) and worked for a while at Elizabeth Downs Station and Wooliana Station (see Fig. 9.1). He has vivid memories of the station manager at Elizabeth Downs 'going off his head' and firing a rifle at all and sundry because someone had borrowed the truck without asking.

During this time, he recalls another uncle deciding to walk a long distance because he had run out of tobacco. The uncle then got very sick. Mr J made a bed of branches in a tree for his uncle to have some respite from the mosquitoes but during the night the old man fell out. Mr J. spent some hours trying to lift him back in and commented, 'by gee he was heavy'. Some time later, Mr J went back to Port Keats to pick up his promised wife. But she had been given to someone else. He 'got wild' and left for a life in the pastoral industry.

During the next 15 years Mr J worked at Litchfield Station, Carlton Station, Billinuna Station, Ivanhoe Station, Legune Station (see Fig. 9.1), Mirrawong, and other cattle properties in the NT and Western Australia (WA). He is known as having been an excellent stockman and rodeo rider (as were others from Port Keats), riding in various events in WA and the NT. During this period of his life, Mr J also attended 'five different types of ceremonies in Kununurra, Halls Creek and Billinuna' that were performed by Aboriginal people from WA. In the 1970s, Mr J came back to the Port Keats area and joined a stock camp at Palumpa Station. Mr J was later elected to the Northern Land Council and served for many years, at one stage visiting the United States for business.

In recent years, $\mathrm{Mr} \mathrm{J}$ has lived on his country, which is about $20 \mathrm{~km}$ from Wadeye. He speaks Murrinh-patha as his primary language, is the most senior leader of his clan group, and is also well-regarded as a ceremony leader. In 2003, 
when the first elections for the Thamarrurr Regional Council were held, each clan group, by constitution, had the right to elect two councillors each. I visited each of the 20 clans on their own country with local Aboriginal people and Council officials to explain why the council was being established, the process, and the need for each group to conduct an election. Mr J, as the leader of his clan, spoke with passion. He spoke about his life-'a bloody hard life I tell you' - and the need 'for the young fellas to stand up and work for their people'. He said that his life was almost at an end but he was happy with the new Thamarrurr Council entity because 'blackfellas could now have the same rights as whitefellas'.

After about an hour of oration, during which Mr J talked about the need for young people to 'stand up', he declared that he had decided not to sit on the council himself. On behalf of the clan, he said, two women would be the representatives. But he would be 'looking over their shoulder to make sure they do the right thing. They got to report back by geez!' The women have subsequently been regular attendees at council meetings. Mr J rarely attends, but when he does he always has something to say, which is accepted by those present with respect. On occasions, $\mathrm{Mr} \mathrm{J}$ also attends some informal community meetings at places such as Peppiminarti, 'caucusing' on issues and he still has a very strong presence in the region. He is one of a number of elderly men who have heightened status across most clans and age groups.

$\mathrm{Mr} \mathrm{J}$ has resided on his clan estate for many years now, driving into the Wadeye township each day to conduct social and business affairs. Despite ill health, he has no regrets, a contented attitude to life, is very proud of his career in the cattle industry, and interestingly, does not speak with any real bitterness about missionaries, stockmen or anyone else for that matter. His leadership style might be described as broad ranging, with leadership and social networks established far beyond Port Keats and extending into WA. Mr J maintains and nurtures such relationships with other leaders, often visiting for ceremonies, funerals and other activities.

\section{Case study B}

Mr N was born at the Wadeye mission hospital in 1957. His father's clan estate was the original landing site of the early missionaries in 1934. Mr N lived in the mission dormitory for 'about 6 or 7 years'. Like Mr J, he still recalls his dormitory identification number. On the weekends he was allowed home to stay with his family. Mr N remembers these days as being 'good fun-especially being with my friends in that age group'. This age group was made up of young men from all of the various tribes 'mixed up'.

Mr N describes a 'turning point' in his life. This was in 1970 when he visited Brisbane and other places. He says: 
We saw how other people live. It was the first time we had seen a big city. We were very well looked after and respected by strangers. I started to realise that there are people out there that don't care where you come from.

He attended a private high school in Victoria during the period 1971-73 and went on to complete Year 12. He remembers it as 'good times', particularly when mixing with boys from Nauru and Central Australia. He says, 'I got to know a lot of people', but also that he saw racism - not so much directed at him but to other Indigenous students. These students were referred to with such names as 'the blackies'. After observing this, $\mathrm{Mr} \mathrm{N}$ said that it actually made him more resolute - 'So now I can take anything'.

Mr N underwent djenbitj (initiation) in Darwin Hospital. In 1978, he commenced his ceremonial introduction into the senior ceremonies. The initial ceremony took place at a site where a major gas pipeline is currently being built. Other men being initiated were from his dormitory group and they went through at the same time. He says, 'The old men really gave us a lesson. They made us sit down and talk things over'.

Mr N says that his father said to him as a young boy 'One day you will take my place as a leader'. But his father also said that 'I want you to go down south to study. It is better that way'. Mr N says, 'But I missed a lot of stuff [culture]'. In 1983 his father died. Mr N says that his father 'In Council meetings ... was strong but he would also let other people have their say'.

$\mathrm{Mr} \mathrm{N}$ returned to Wadeye following his education in Victoria and began to pursue a career as a teacher at the Catholic school at Wadeye. Whilst rising through the ranks of the NT education system, he has also become a prominent and influential member of the local council.

Reflecting on where he is today as a senior educational official in the Wadeye community and an influential spokesperson on intercultural affairs, Mr N says: 'If we hadn't been made to speak English at school-I would never have gone on to matriculation'. He argues: 'This is important - you have to be able to speak English whether you like it or not'. Mr N maintains cordial relations with most clan leaders in the Port Keats region and is highly regarded. He often acts as a negotiator and peacekeeper. He is of the Kardu Keke age bracket (see Fig. 9.2) and has been delegated various responsibilities by senior clan leaders. Such status enables him to effectively operate and negotiate with non-Indigenous interests as well.

\section{Case study C}

$\mathrm{Mr} \mathrm{K}$ is in his late twenties. He is a large man with an imposing presence. For many years he has been regarded as the leader of one of the youth groups or 
'gangs'. He prefers to refer to the group as 'family'. Mr K attended boarding school in Darwin to Year 10. He has been charged by the police on many occasions, usually for assault, and has spent much of the last 10 years of his life in prison.

$\mathrm{Mr} \mathrm{K}$ has a large following of male and female supporters, most of whom are younger than him. He is called on, and usually responds, to lead battles against other groups or to intervene in matters of contention. He is rarely involved in routine events in the community and for many years was not even seen enough to be recognisable by non-Indigenous residents (although most have heard his name).

$\mathrm{Mr} \mathrm{K}$ has a reasonable knowledge of matters related to his estate but does not participate very often in ritual affairs. He regards this as the fault of elders in the community. The elders have often been reluctant, he says, to pass on information of sacred importance to some individuals in case it is used wrongfully. Mr K's relationship with the other two levels of leadership in Wadeye - the elderly and middle-aged - is terse, although is improving noticeably as he grows older. In more recent times, Mr K's relationship with the police has also improved and this has generally translated into a better state of community affairs.

$\mathrm{Mr} \mathrm{K}$ is regarded as a strong leader by his young followers and many fellow clan members, and they revere his strength of character. However, unlike Mr J and $\mathrm{Mr} \mathrm{N}$, he is yet to gain credibility in the wider community arena of leadership. This could change if his style becomes more peaceful and embracing of others. The other leaders previously mentioned, $\mathrm{Mr} \mathrm{J}$ and $\mathrm{Mr} \mathrm{N}$, have developed networks of leadership, particularly through their work experience, whilst $\mathrm{Mr}$ K's opportunities to construct a leadership base have been mainly restricted to prison or illegal activities.

These three case studies reflect the temporal related life-experience of leaders from the region. ${ }^{23}$ They indicate not only that leadership development begins at an early age and builds over time, but that it also occurs in a particular historical period, which provides a range of associated opportunities that one might experience. Individuals who have worked or studied in environments outside of the immediate region may develop more constructive community roles later in life. The case studies highlight the continuing importance of ceremonial knowledge plus education (not necessarily in the same person), and also the importance of networks in the region. The studies also strongly point to negative styles of engagement, as some individuals progress through life-stages within prison walls.

\footnotetext{
${ }^{23}$ Numerous other case studies have been conducted. They are very detailed and reflect a 'journey' of leadership development.
} 


\section{A model of leadership and engagement}

The general literature on Indigenous Australian leadership emphasises a range of western paradigms, none of which adequately explains the situation at Port Keats. Anthropological perspectives developed in more recent times, whilst examining other regional groups, provide more insight, but in their totality have not yet reached a cohesive analysis that might be both locally relevant and generally applicable.

My research at Port Keats has attempted to develop an ethnographically informed conceptualisation of leadership. The model presented here is of a socially and politically articulated form of leadership founded on inherited and acquired responsibilities of 'looking after' and working for others, which is reproduced by being born on certain country, by having relationships through kin and marriage, and by individual development within complex personal and group networks. In other words, leaders not only have to be born to lead, they also have to build up and maintain their respect.

More specifically, leadership is distributed and reproduced amongst senior men who own particular areas of land through patrilineal affiliation and descent. Their authority is absolute for very specific matters related to such estates and the other men, women and children within the clan, but is negotiable for other matters. Such men participate in regional ceremonial activities that celebrate a higher order of life and being. They extend and nurture their leadership domain by engaging with other leaders and groups in a flexible field of authority that often depends on demonstrating personal qualities such as the ability to understand and care for others. It is through the mobilisation of such networks and resources that such leaders get things done. This is referred to as 'nodal leadership' (see Hunt and Smith 2007: vii). Rarely does a leader become 'wealthy' in a material sense in this environment, although the thickness of their nodal networks suggests they are rich in the sense of human relationships and social capital. This lack of material wealth suggests that their 'bigness' remains vulnerable to the judgment of their peers.

Furthermore, the model acknowledges that leadership is inherently founded on Indigenous social constructs and culturally based institutions and systems. The important theoretical conclusion that can be derived from the daily condition of Indigenous life described here is that leadership must be conceptualised and understood as a form of networked governance based on a nodal framework of leaders across communities and regions. This model of Indigenous leadership has the following characteristics:

1. The networks reflect 'enduring webs' of leadership relationships that are able to both accommodate and persevere in the midst of 'shifting alliances 
and cleavages' between and amongst leaders and groups (Hunt and Smith 2007: 8).

2. Nodal leaders have the capacity to draw on shared histories and mobilise alliances and resources across networks in order to get things done.

3. Such leadership does not translate to the accumulation of material goods or even permanent rights, but represents a web of authority and knowledge that is utilised for the common goals of the group.

4. The system has the occasional prominent or eminent leader, but within a socially-sanctioned network where legitimacy has to continue to be 'earned', eminence relies on recognition within the overall system, the ability to work within the network, the ability to bring to fruition the local potential of that system (i.e. 'get things done'), and the 'thickness' of each individual's networks (nurtured and supported by generosity, reciprocity and other such cultural norms).

5. Leadership can be delegated to certain individuals in order to reproduce and maintain relationships within the colonial intercultural realm.

6. Leaders regularly attempt to engage with other cultural groups, but often fail because of mutual misunderstandings and competition for scarce resources (including followers). This results in misalignment and, occasionally, the fission and fusion of groups and organisations.

The last point is important in the context that Indigenous leaders currently find themselves; for the research at Port Keats indicates a desire by the people, despite years of confusion and misalignment, to continue to strategically engage in order to survive as a social, political and economic entity.

This model of nodal, networked leadership works and is sustainable because:

- it is reasonably 'fluid', negotiable and adaptive to local circumstances in some situations, but constant and know-able (non-negotiable) in others; and

- it reflects the essential duality of Indigenous society's egalitarian and hierarchical nature, incorporates the desire for individual decision-making rights, but is enabling in that it embodies and supports a capacity, in some of the leaders, to move across contexts and mobilise collective action.

\section{The 'gap' in intercultural understanding}

This model suggests that there is a considerable gap in understanding between Indigenous and non-Indigenous sectors about leadership and governance, and that this gap generates political contestation over power and authority in post-colonial Australian society. Some argue that today, delineating culturally distinct governance structures and supporting distinctly Indigenous forms of leadership is no longer relevant or possible and that an intercultural approach is required (Holcombe 2004; Martin 2003; Merlan 1998). While Aboriginal groups at Port Keats have seen over their contact history that their attempts to engage 
in an 'intercultural' domain are extremely problematic, they have initiated several innovative attempts to transform and insert their culturally-based model of leadership into their interactions with the Australian state. However, with limited legal or policy recognition of their own governance systems and leadership networks, Indigenous leaders at Wadeye remain firmly embedded within an Indigenous 'domain'.

Sinclair (2007: 128) argues that leadership identity is created within 'a negotiated process that takes place within a politically charged organisational and social space'. Further, she argues that people face pressures in mainstream society to produce the 'right' leadership identity (ibid. 131). Feel for the Indigenous leader then, who has to operate and engage in both 'traditional' and mainstream domains. There are high expectations to deliver outcomes within the kind of group-orientated Indigenous framework as described in this chapter; and the state and its implicit policy goal to create the 'right' types of Indigenous leadership has created a negative environment over a long period. It is not surprising therefore that despite recent positive events ${ }^{24}$ the current restlessness of youth at Port Keats underlies another perspective from some locals. That is, that whilst their leaders lead at home, beyond the reserve boundary they are, as one old Murrinh-patha man said in the 1970s, 'makardu', a nobody, with limited power and authority (see Fr J. Leary cited in McCormack 2006).

\section{Conclusion}

My research indicates that Indigenous leadership today in northwest Northern Australia can be described as a model of networked authority, which is inter-relational and nodal in nature, and which provides a system of governing order for a given group or society and for individuals. It affords morals and meaning in a demanding, challenging and changing environment. Such nodal, networked leadership comprises a coherent internal entity and has been an important survival mechanism for many Indigenous groups. At its most effective, this Indigenous leadership model enables various loci of events and intercultural articulations to occur and be incorporated, and subsequently perpetuate the system. When the external power of the state overrides and prevails, the governance and transformative benefits of Indigenous leadership are greatly diminished.

Unfortunately, this system of authority is often imperceptible to those 'outside' it, and this 'invisibility' often has adverse consequences. Given this situation, the reality is that Indigenous leadership in many areas of remote Australia is

\footnotetext{
${ }^{24}$ In 2006, the senior men began an initiative to discuss key issues with the younger members of the community who were causing problems. A jointly planned move to re-establish some living areas on clan estates and land management activities was made to the satisfaction of most concerned. This relationship, and assistance, peaks and wanes depending on dysfunctional activities of the youth and conflict between groups.
} 
under extreme threat. Nevertheless, the research has also outlined how, when under threat or challenge, Indigenous leadership can demonstrate its considerable resilience. Leadership is generally proposed as being a fundamental component of legitimate and effective, 'good' governance. If Indigenous people, irrespective of where they live in the world, are to be justly and fairly recognised in wider society, then this recognition needs to be founded in leadership and authority structures that are relevant to Indigenous people themselves, and which provide a recognised link to dominant institutions. It is important for non-Indigenous Australia to understand and work with the dynamics of Indigenous leadership, particularly as young leaders emerge. Just as important is the need for Indigenous people to appreciate the leadership constructs of the dominant society and the distinct nature of their own leadership.

\section{Acknowledgements}

Diane Smith has provided advice and assistance with the preparation of this paper. Her on-going support throughout this process has been gratefully received. Kate Senior, my principal $\mathrm{PhD}$ supervisor, has also provided valuable advice and support. I also thank Will Sanders, John Taylor, Janet Hunt, Stephanie Garling and fellow researchers at CAEPR for their advice and assistance and the two anonymous reviewers for their helpful comments. Dominic McCormack, Tobias Nganbe and Leon Melpi have always provided expert and insightful advice in the field. Kevin Wanganeen, Terry Bullimore, Dale Seaniger, Rick Bliss, Mandy Leggatt, Mark Crocombe and John Marchant at Wadeye as well as Kevin, Nicole and Andrew at the North Australian Research Unit have been very supportive and helpful, and I thank them. My research is supported by Charles Darwin University, the Menzies School of Health Research and CAEPR, ANU. Most importantly, I have been advised and guided over the years by Aboriginal men and women from the Port Keats region and I am extremely grateful for their patience, knowledge and support.

\section{References}

Ah Kit, J. The Hon. 2002. Ministerial Statement, delivered as Minister assisting the Chief Minister on Indigenous Affairs, 7 March, Northern Territory Government, Darwin.

Anderson, C. 1988. 'All bosses are not created equal', Anthropological Forum, 4: 507-23.

Anderson, P. and Wild, R. 2007. Ampe Akelyernemane Meke Mekarle-Little Children Are Sacred, Report of the Northern Territory Board of Inquiry into the Protection of Aboriginal Children from Sexual Abuse, Report to the Northern Territory Government, Darwin, available at $<$ http://www.nt.gov.au/dcm/inquirysaac/> 
Australian Broadcasting Corporation (ABC) 2007. 'We don't need the army: Indigenous leaders', $A B C$ News Online, 25 June, available at <http://www.abc.net.au/news/stories/2007/06/25/1961525.htm> [accessed 26 June 2007].

Billot, C. P. 1979. John Batman: John Batman and the Founding of Melbourne, Hyland House, Melbourne.

Biskup, P. 1973. Not Slaves Not Citizens: The Aboriginal Problem in Western Australia, 1898-1954, University of Queensland Press, St Lucia.

Bern, J. 1979. 'Ideology and domination: toward a reconstruction of Australian Aboriginal social formation', Oceania, 50 (2): 118-32.

Berndt, R. M. and Berndt, C. H. 1965. Aboriginal Man in Australia: Essays in Honour of Emeritus Professor A. P. Elkin, Angus \& Robertson, Sydney.

Bride, T. F. 1969. Letters from Victorian Pioneers: Being a Series of Papers on the Early Occupation of the Colony, the Aborigines, etc., Heinemann, Melbourne.

Burch, E. S. and Ellanna, L. J. (eds) 1994. Key Issues in Hunter-Gatherer Research, Berg, Oxford.

Burridge, K. 1973. Encountering Aborigines, a Case Study: Anthropology and the Australian Aboriginal, Pergamon Press, New York.

Chase, A. 1984. 'Belonging to country: territory, identity and environment in Cape York Peninsula, Northern Australia', in L. R. Hiatt (ed.), Aboriginal Landowners: Contemporary Issues in the Determination of Traditional Aboriginal Land Ownership, Oceania Monograph No. 27, University of Sydney, Sydney.

Collins, D. 1804. An Account of the English Colony in New South Wales, Cadell \& Davies, London.

Collman, J. 1988. Fringe-Dwellers and Welfare: The Aboriginal Response to Bureaucracy, University of Queensland Press, St Lucia.

Curr, E. M. 1886. The Australian Race: Its Origin, Languages, Customs, Place of Landing in Australia and the Routes By Which It Spread Itself Over that Continent, J. Ferres, Government Printer, Melbourne.

Dawson, J. 1881. Australian Aborigines: The Languages and Customs of Several Tribes of Aborigines in the Western District of Victoria, Australia, G. Robertson, Melbourne.

Desmarchelier, X. 2000. Background Presentation: A Historical and Cultural Overview to the Re-emergence of Thamarrurr a Traditional Form of Governance for the People of Wadeye Region, Unpublished report 
prepared by the people of Wadeye on behalf of Thamarrurr Incorporated, Thamarrurr, Wadeye.

Dixon, R. M. W. 2002. Australian Languages: Their Nature and Development, Cambridge University Press, Cambridge.

Edwards, W. H. (ed.) 1987. Traditional Aboriginal Society: A Reader, Macmillan, South Melbourne.

Elkin, A. P. 1938. The Australian Aborigines: How to Understand Them, Angus \& Robertson, Sydney.

Eyre, E. 1845. Journals of Expeditions of Discovery into Central Australia, and Overland from Adelaide to King George's Sound, Sent by the Colonists of South Australia, With the Sanction and Support of the Government: Including an Account of the Manners and Customs of the Aborigines and the State of Their Relations with Europeans, T. \& W. Boone, London.

Falkenberg, A. and Falkenberg, J. 1981. The Affinal Relationship System: A New Approach to Kinship and Marriage Among the Australian Aborigines at Port Keats, Universitetsforlaget, Oslo.

Flanagan, R. J. 1888. The Aborigines of Australia, E. F. Flanagan and G. Robertson and Co., Sydney.

Furlan, A. 2005. Songs of Continuity and Change: The Reproduction of Aboriginal Culture through Traditional and Popular Music, PhD Thesis, University of Sydney, Sydney.

Gerritsen, R. 1981. 'Thoughts on Camelot: from Herodians and Zealots to the contemporary politics of remote Aboriginal settlement in the Northern Territory', Paper presented to The Australasian Political Studies Association 23rd Annual Conference, ANU, Canberra.

Grey, G. 1841. Journals of Two Expeditions of Discovery in North-West and Western Australia, During the Years 1837, 38, and 39 ... With Observations on the Moral and Physical Condition of the Aboriginal Inhabitants, \&c. \&c., T. $\&$ W. Boone, London.

Gould, R. A. 1969. Yiwara: Foragers of the Australian Desert, Collins, London.

Hiatt, L. R. 1965. Kinship and Conflict: A Study of an Aboriginal Community in Northern Arnhem Land, Australian National University, Canberra.

-1986. Aboriginal Political Life, Australian Institute of Aboriginal Studies, Canberra.

Hiatt, L. R. 1996. Arguments about Aborigines: Australia and the Evolution of Social Anthropology, Cambridge University Press, Cambridge. 
Hirst, J. 2007. 'The myth of a new paternalism', The Australian, 26 June, available at <http://www.theaustralian.news.com.au/story/0,20867,219662577583,00.html $>$.

Holcombe, S. 2004. 'Socio-political perspectives on localism and regionalism in the Pintupi Luritja region of central Australia: implications for service delivery and governance', CAEPR Working Paper No. 25, CAEPR, ANU, Canberra.

Howard, J. The Hon. and Brough, M. The Hon. 2007. 'Joint Press Conference with The Hon. Mal Brough, for Families, Community Services and Indigenous Affairs, Canberra', Interview Transcript, 21 June, available at <http://pandora.nla.gov.au/pan/10052/20070823-1732/

www.pm.gov.au/media/Interview/2007/Interview24380.html $>$ [accessed 24 April 2008].

Howitt, A. W. 1967. 'The Kurnai: their customs in peace and war', in L. Fison and A. W. Howitt, Kamilaroi and Kurnai: Group-Marriage and Relationship, and Marriage by Elopement, Drawn Chiefly from the Usage of the Australia Aborigines; also, The Kurnai Tribe: Their Customs in Peace and War, Anthropological Publications, Oosterhout.

Hughes, H. 2005. 'Policies entrench poverty', The Australian, 23 September, available at <http://www.cis.org.au/executive_highlights/EH2005/ eh30205.html $>$.

Hunt, J. and Smith, D. E. 2007. 'Indigenous Community Governance Project: year two research findings', CAEPR Working Paper No. 36, CAEPR, CASS, ANU, Canberra.

Ivory, B. 2003. Nemarluk to Heavy Metal: Cultural Change and the Development of Contemporary Youth Sub-culture at Port Keats, Northern Territory, BA (Hons) Thesis, Charles Darwin University, Darwin.

2005a. 'Indigenous governance and leadership: a case study from the Thamarrurr (Port Keats) region in the Northern Territory', ICGP Occasional Paper No. 8, CAEPR, ANU, Canberra.

-2005b. 'Leadership: issues and principles from the Thamarrurr (Port Keats) region of the Northern Territory', ICGP Occasional Paper No. 12, CAEPR, ANU, Canberra.

2006. 'The problem of leadership: research from the Port Keats region of the Northern Territory', Paper presented in Anthropology Seminar Series, 7 April, Charles Darwin University, Darwin.

2007. 'Indigenous leadership: critical events in the northwest of the Northern Territory 1870-1935', Paper presented in the Anthropology Seminar Series, 20 April, Charles Darwin University, Darwin. 
Keen, I. 1982. 'How some Murngin men marry ten wives: the marital implications of matrilineal cross-cousin structures', Man, 17 (4): 620-42.

1994. Knowledge and Secrecy in an Aboriginal Religion, Clarendon Press, Oxford.

2006. 'Constraints on the development of enduring inequalities in Late Holocene Australia', Current Anthropology, 47 (1): 7-38.

Kolig, E. 1981. The Silent Revolution: The Effects of Modernization on Australian Aboriginal Religion, Institute for the Study of Human Issues, Philadelphia.

McCormack, D. 2006. 'The substance of Australia's first men', Paper presented to the National Mental Health and Homelessness Advisory Committee of St Vincent de Paul Society, 20 July, Darwin, available at <http://www.bowden-mccormack.com.au/uploads/articles-papers/ substance-first-men.pdf $>$.

Maddock, K. 1972. The Australian Aborigines: A Portrait of Their Society, Allen Lane, London.

Martin, D. 2003. 'Rethinking the design of Indigenous organisations: the need for strategic engagement', CAEPR Discussion Paper No. 248, CAEPR, ANU, Canberra.

Marett, A. 2005. Songs, Dreaming, and Ghosts: The Wangga of North Australia, Wesleyan University Press, Middletown.

McAdam, E. The Hon. 2006. 'Local government reform in the Northern Territory', Statement from the Minister for Local Government, 11 October 2006, available at <http://www.localgovernment.nt.gov.au/_data/assets/ pdf_file/0018/5931/McAdam_Statement_061011.pdf $>$ [accessed 5 May 2008].

Meggitt, M. 1962. Desert People: A Study of the Walbiri Aborigines of Central Australia, Angus \& Robertson, Sydney.

Merlan, F. 1998. Caging the Rainbow: Places, Politics and Aborigines in a North Australian Town, University of Hawai'i Press, Honolulu.

Myers, F. R. 1976. To Have and To Hold: A Study of Persistence and Change in Pintupi Social Life, PhD Thesis, University of Michigan, Ann Arbor.

Radcliffe-Brown, A. 1913. 'Three tribes of Western Australia', Journal of the Royal Anthropological Institute, 43: 143-94.

Rigsby, B. 1997. 'Structural parallelism and convergence in the Princess Charlotte Bay languages', in P. McConvell and N. Evans (eds), Archaeology and Linguistics: Aboriginal Australia in Global Perspective, Oxford University Press, Melbourne. 
Rowse, T. 1998. White Flour, White Power: From Rations to Citizenship in Central Australia, Cambridge University Press, Melbourne.

Sackett, L. 1978. 'Punishment as ritual: "man-making" among Western Desert Aborigines', Oceania, 49: 110-27.

Sansom, B. 1980. The Camp at Wallaby Cross: Aboriginal Fringe Dwellers in Darwin, AIAS New Series No. 18, Australian Institute of Aboriginal Studies, Canberra.

Sharp, L. 1958. 'People without politics', in V. Ray (ed.), Systems of Political Control and Bureaucracy in Human Societies, University of Washington Press, Seattle.

Sinclair, A. 2007. Leadership for the Disillusioned: Moving Beyond Myths and Heroes to Leading That Liberates, Allen \& Unwin, Crows Nest.

Smith (von Sturmer), D. E. 1976. Past-Masters Now: A Study of the Relationship between Anthropology and Australian Aboriginal Societies, BA (Hons) thesis, Department of Anthropology, University of Queensland, St Lucia.

Smith, D. E. 1984. “"That register business": the role of the Land Councils in determining traditional Aboriginal owners', in L. R. Hiatt (ed.), Aboriginal Landowners: Contemporary Issues in the Determination of Traditional Aboriginal Land Ownership, Oceania Monograph No. 27, University of Sydney, Sydney.

-1997. 'From humbug to good faith? The politics of negotiating the right to negotiate', in J. Finlayson and D. E. Smith (eds), Fighting Over Country: Anthropological Perspectives, CAEPR Research Monograph No. 12, CAEPR, ANU, Canberra.

Smyth, R. B. 1878. The Aborigines of Victoria: With Notes Relating to the Habits of the Natives of Other Parts of Australia and Tasmania, Government Printer, Melbourne.

Spencer, B. and Gillen, F. J. 1938. The Native Tribes of Central Australia, Macmillan, London.

Stanner, W. E. H. 1964. On Aboriginal Religion, Oceania Monograph No. 11, University of Sydney Press, Sydney.

-1979. White Man Got No Dreaming: Essays 1938-1973, ANU Press, Canberra.

Strehlow, T. G. H. 1947. Aranda Traditions, Melbourne University Press, Melbourne.

Sutton, P. 1978. Aboriginal Society: Territoriality and Language at Cape Kerweer, Cape York Peninsula, PhD Thesis, University of Queensland, St Lucia.

— and Rigsby, B. 1982. 'People with 'politicks': management of land and personnel on Australia's Cape York Peninsula', in N. M. Williams and 
E. S. Hunn (eds), Resource Managers: North American and Australian Hunter-Gatherers, Westview Press for the American Association for the Advancement of Science, Boulder.

Taplin, G. 1874. The Narrinyeri: An Account of the Tribes of South Australian Aborigines Inhabiting the Country Around the Lakes Alexandrina, Albert, and Coorong, and the Lower Part of the River Murray ... , Shawyer, Adelaide.

Taylor, J. 2004. Social Indicators for Aboriginal Governance: Insights from the Thamarrurr Region, Northern Territory, CAEPR Research Monograph No. 24, ANU E Press, ANU, Canberra.

Tench, W. 1961. Sydney's First Four Years: Being a Reprint of A Narrative of the Expedition to Botany Bay and a Complete Account of the Settlement at Port Jackson, Angus \& Robertson, Sydney.

Thamarrurr Regional Council 1995. Thamarrurr Council of Elders, Thamarrurr Regional Council, Wadeye.

Thomas, N. 1906. Kinship Organisations and Group Marriage in Australia, Cambridge University Press, Cambridge.

Tonkinson, R. 1991. The Mardu Aborigines: Living the Dream in Australia's Desert, Holt, Rinehart and Winston, Fort Worth.

Trigger, D. S. 1992. Whitefella Comin': Aboriginal Responses to Colonialism in Northern Australia, Cambridge University Press, Cambridge.

von Sturmer, J. R. 1978. The Wik Region: Economy, Territoriality and Totemism in Western Cape York Peninsula, North Queensland, PhD Thesis, University of Queensland, St Lucia.

Wheeler, G. C. 1910. The Tribe, and Intertribal Relations in Australia, J. Murray, London.

Wilkes, C. 1845. Narrative of the United States Exploring Expedition, During the Years 1838, 1839, 1840, 1841, 1842, Lea \& Blanchard, Philadelphia.

Williams, N. M. 1987. Two Laws: Managing Disputes in a Contemporary Aboriginal Community, Australian Institute of Aboriginal Studies, Canberra. 